\title{
Can God create humans with free will who never commit evil?
}

\begin{tabular}{|c|c|}
\hline $\begin{array}{l}\text { Authors: } \\
\text { Lee Pham Tha } \\
\text { Jerry Pillay² }\end{array}$ & \\
\hline $\begin{array}{l}\text { Affiliations: } \\
\text { 1Department } \\
\text { and Historical } \\
\text { Faculty of The } \\
\text { Religion, Univ } \\
\text { Pretoria, Pret } \\
\text { South Africa }\end{array}$ & $\begin{array}{l}\text { of Systematic } \\
\text { Theology, } \\
\text { ology and } \\
\text { ersity of } \\
\text { oria, }\end{array}$ \\
\hline $\begin{array}{l}{ }^{2} \text { Department } \\
\text { History and Cl} \\
\text { Faculty of The } \\
\text { Religion, Univ } \\
\text { Pretoria, Pret } \\
\text { South Africa }\end{array}$ & $\begin{array}{l}\text { of Church } \\
\text { hurch Polity, } \\
\text { ology and } \\
\text { ersity of } \\
\text { pria, }\end{array}$ \\
\hline $\begin{array}{l}\text { Project Resea } \\
\text { Project Leade } \\
\text { Project Numb }\end{array}$ & $\begin{array}{l}\text { ch Registration: } \\
\text { r: J. Pillay } \\
\text { er: } 04653484\end{array}$ \\
\hline $\begin{array}{l}\text { Description: } \\
\text { This research } \\
\text { project, 'Africa } \\
\text { and Developm } \\
\text { by Prof. Dr Jer } \\
\text { Department o } \\
\text { History and Cl } \\
\text { Faculty of The } \\
\text { Religion, Univ } \\
\text { Pretoria. }\end{array}$ & $\begin{array}{l}\text { s part of the } \\
\text { in Christianity } \\
\text { ent', directed } \\
\text { ry Pillay, } \\
\text { f Church } \\
\text { urch Polity, } \\
\text { ology and } \\
\text { ersity of }\end{array}$ \\
\hline $\begin{array}{l}\text { Correspondin } \\
\text { Jerry Pillay, } \\
\text { jerry.pillay@u }\end{array}$ & $\begin{array}{l}\text { g author: } \\
\text { p.ac.za }\end{array}$ \\
\hline $\begin{array}{l}\text { Dates: } \\
\text { Received: } 09 \text { I } \\
\text { Accepted: } 01 \\
\text { Published: } 22\end{array}$ & $\begin{array}{l}\text { May } 2020 \\
\text { Aug. } 2020 \\
\text { Oct. } 2020\end{array}$ \\
\hline $\begin{array}{l}\text { How to cite th } \\
\text { Thai, L.P. \& Pil } \\
\text { 'Can God crea } \\
\text { free will who } \\
\text { evil?', HTS Teo } \\
\text { Theological St } \\
\text { a6102. https:/ } \\
\text { 10.4102/hts.v }\end{array}$ & $\begin{array}{l}\text { is article: } \\
\text { lay, J., 2020, } \\
\text { te humans with } \\
\text { eever commit } \\
\text { logiese Studies/ } \\
\text { udies 76(1), } \\
\text { /doi.org/ } \\
76 i 1.6102\end{array}$ \\
\hline $\begin{array}{l}\text { Copyright: } \\
\text { (c) 2020. The } \\
\text { Licensee: AOS } \\
\text { is licensed un } \\
\text { Creative Comr } \\
\text { Attribution Lic }\end{array}$ & $\begin{array}{l}\text { uthors. } \\
\text { S. This work } \\
\text { ler the } \\
\text { nons } \\
\text { ense. }\end{array}$ \\
\hline Read online & \\
\hline 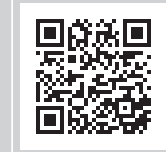 & $\begin{array}{l}\text { Scan this QR } \\
\text { code with your } \\
\text { smart phone or } \\
\text { mobile device } \\
\text { to read online. }\end{array}$ \\
\hline
\end{tabular}

Can an omnipotent and omnibenevolent God create humans with free will without the capacity to commit evil? Scholars have taken opposite positions on the contentious problem. Using scripture and the rules of logic, we argue that God cannot create impeccable creatures because of his 'simplicity'. God cannot create gods, because God is uncreated. Peccable humans freely choose to disobey their creator and thus cannot blame him for the horrendous evils in this world. Concerning the belief of sinless humans with free will in heaven, we suggest that such an impartation of God's impeccability can be accomplished, not through creation, but by the marriage of Christ and the Church, for the two shall become one. Believers will become children of God and partakers of the divine nature.

Contribution: Theologians and philosophers have argued whether God could create humans with free will who never commit evil, and if he could, why did he not do so? The primary contribution of this article is the argument that God could not create impeccable humans with free will for God could not create gods.

Keywords: free will; evil; impeccability; God's simplicity; marriage.

\section{Introduction}

Why did God create humans with the capacity to sin? Would it not be better to have beings with free will who never commit evil? Did God err in making this realm with its 'horrendous evils' (Adams 2006)? Should one give up on believing in the existence of an omnibenevolent creator?

These issues have been brought to the fore by the debate on the 'logical problem of evil' (HowardSnyder 2013). Mackie (1955:209) claimed that an omnipotent God could prevent all evils by creating humans with free will who never commit evil. 'Clearly, his failure to avail himself of this possibility is inconsistent with his being both omnipotent and wholly good'. Schellenberg (2013) concurred:

[I]f for any world $\mathrm{X}$ that requires or permits evil there is some world $\mathrm{Y}$ that models pure goodness in God such that God has no good reason to create X rather than Y, then God has no good reason to permit evil in the world. (p. 42)

In his 'free will defence', Plantinga (1974:180-184) responded with 'Leibniz's lapse', that is, contrary to Leibniz's assertion, ${ }^{1}$ there are some worlds that not even an omnipotent God can create, a world populated by people with free will who never commit evil. Although Mackie's proposed world is theoretically possible, it could not be actualised according to Plantinga's theory of 'transworld depravity': 'If every essence suffers from transworld depravity, then it was beyond the power of God himself to create a world containing moral good but no moral evil'. ${ }^{2}$

Howard-Snyder (2013) countered with the opposite theory of 'transworld sanctity (TWS)':

$[T]$ he reason why it is reasonable to refrain from believing D (Transworld Depravity) is that there is a proposition that we know is incompatible with $\mathrm{D}$, and it is no more reasonable to believe $\mathrm{D}$ than it.

1.The German philosopher Leibniz claimed that our world is 'the best of all possible worlds' that God could create (Leibniz 1951 : 345-355). 'As omnipotent, God is able to create any possible world He chooses to create' (Steinberg 2007:123).

2.Plantinga (1977:53). Otte pointed out some weaknesses of Plantinga's 'transworld depravity' and suggested a better definition of the theory (Otte 2009:168). Plantinga agreed and adopted the new definition (Plantinga 2009:178-191). 
That proposition is S: Necessarily, some essence or other enjoys Transworld Sanctity (TWS:24). ${ }^{3}$

Furthermore, Plantinga's claim that God cannot create beings with free will without evil appears to contradict the classical view of heaven, where sanctified dwellers have free will in the absence of evil. Augustine said, concerning eternal felicity in the City of God: 'Man should first receive a free will by which he was able not to sin, and at last a free will by which he was not able to $\sin ^{\prime}{ }^{4}$ Gaine (2003) affirmed:

$[I] \mathrm{n}$ the beatific vision, however, both angels and human beings are unable to $\sin . .$. that impeccability belongs to the orthodox Christian concept of heaven is thus beyond any doubt. (pp. 9-11)

Fales (2013:358) argued that God can make perfect creatures (PC) who never sin: 'I will call such a creature a perfect creature (PC), a creature that is an exact duplicate of God save for one characteristic: aseity'. Hick (2017:268) opined: 'It appears to me that a perfectly good being, although formally free to $\sin$, would in fact never do so'.

In this article, we will first argue that God cannot create a PC because of God's 'simplicity'. Because God is one with his attributes, ${ }^{5}$ he cannot create beings with the attribute of impeccability without making them gods. In the monotheistic context of our discussion, God cannot create gods because God is uncreated. ${ }^{6}$ Second, we will contend that the presence of evil in this realm cannot be blamed on God or used to question his existence or benevolence. Finally, concerning the sinlessness of humans with free will ${ }^{7}$ in heaven, we will suggest that such an impartation of God's impeccability can be accomplished, not through creation, but by the marriage of Christ and the Church, for the 'two shall become one' (Eph 5:31-32).

\section{God's impeccability}

Brümmer (2006:271) said: 'God's perfect goodness has generally been held to entail that he has the attribute not only of impeccantia [freedom from sin], but also of impeccabilitas [inability to sin]'. Impeccability is 'the inability to do what is morally wrong' ${ }^{8}$ Henderson observed that impeccability requires more than just an inability to commit evil actions; it also emphasises the additional quality of moral virtue.' 'God, who, being most holy and righteous,

3.Howard-Snyder (2013:24). Plantinga disagreed that 'transworld sanctity' is just as likely as 'transworld depravity' (Plantinga 2009:178-191).

4.Augustine (1972). Henderson concurred: 'The redeemed in heaven will be impeccable forever' (Henderson 2017:179).

5. God is what he has, in whom 'quality and substance are identical' (Augustine 1972, XI.10)

6.'There is only one God. He is uncreated and infinite' (Swedenborg 1813:1). The Athanasian Creed stated: 'Uncreated is the Father; uncreated is the Son; uncreated is the Spirit' (https://www.newworldencyclopedia.org/entry/Athanasian_Creed).

7.Although sympathetic to libertarian free will, our proposal can also accommodate compatibilist free will.

8.Wierenga (1898:203). Wierenga added: 'God is essentially good ... God is impeccable ... The problem of evil is frequently thought to constitute the leading challenge to the doctrine that God is good'.

9.'Under this conception of impeccability, the agent not only will be unable to perform acts of $\sin$ or evil, the agent's character will be so virtuous that he or she will be unable to form the desire, motivation, and intention to perform acts of sin or evil' (Henderson 2017:180) neither is nor can be the author or approver of $\sin ^{\prime} .{ }^{10}$ Thus, the morally virtuous God does not $\sin$, cannot $\sin ,{ }^{11}$ is not the author of sin, cannot be tempted by evil and does not tempt anyone to $\sin$ (Ja 1:13).

\section{God's simplicity}

There are many attributes of God (e.g. omnipotence, omniscience, omnibenevolence), as discussed in works by various scholars (Berkhof 1941; Erickson 2013; Grudem 1994). God's attributes are not a collection of characteristics added together; nor are they additions to his being. Aquinas said: 'It is clear that God is nowise composite but is altogether simple'. ${ }^{12}$ Augustine wrote: 'What is meant by "simple" is that its [God's] being is identical with its attributes'. ${ }^{13}$ Anselm (2007:24) concurred: 'That he [God] is simple in such a way that all the things that can be said of his essence are one and the same thing in him'. All of God's attributes are parts and parcels of himself and cannot be separated from him. Grudem (1994:179) opined: 'God's whole being includes all of his attributes ... every attribute of God also qualifies every other attribute [emphasis in original]'.

As an analogy, a diamond has four characteristics: carat, cut, colour and clarity. The cut impacts the carat of the final product. The carat of the original stone may determine its cut. The clarity of the gem may impact its colour. The colour of the raw specimen may influence the way it is cut. Likewise, the attributes of God are not divisible and separate. ${ }^{14}$ They are all one and the same with God. Berkhof (1941:44) wrote: 'From the simplicity of God, it follows that God and his attributes are one'. Augustine affirmed: 'We say it [the Trinity] is simple, because it is what it has' ${ }^{\prime 15}$

The attributes of God are like the facets of a precious stone. Each attribute describes the same gem, although with a different emphasis (God's just love vs. God's loving justice). A diamond's attribute cannot be transmitted piecemeal to a different material. For example, a diamond's 'clarity' cannot be given to iron. The four Cs of a diamond, if transmitted, must be imparted as a whole. Likewise, God's attributes (or better, 'attribute'), if given, must be conveyed in toto. ${ }^{16}$ If so, can God create a human with free will who never sins, as claimed by Mackie and Schellenberg?

10.The Westminster Confession of Faith (Chapter V, Section 4). The Westminster Confession also stated: 'There is but one only, living, and true God' (Chapter II, Section 1).

11.God's impeccability is commonly accepted (see Echavarria 2018:1-18).

12.Aquinas $(1981,1.3 .7)$. He further added: 'Since God is absolute form, or rather absolute being, He can be in no way composite'. He also quoted Augustine's sayings (De Trin. iv, 6, 7): "God is truly and absolutely simple"' (Summa Theologica, 1.3.7).

13.Augustine (1972:XI. 10). He explained: 'The reason why a nature is called simple is that it cannot lose any attribute it possesses, that there is no difference between what it is and what it has'

14.Besides being indivisible in attribute, according to Wittman, 'God is indivisible in being and therefore in activity. Hence, the doctrine that the Trinity's external works are indivisible (opera trinitatis ad extra indivisa sunt)' (Wittman 2018:359-380).

15.Augustine (1972:XI. 10). He elaborated further: 'The Trinity is called simple, because it has not anything which it can lose, and because it is not one thing and its contents another'.

16.Theologians sometimes classify the attributes of God as 'communicable' versus 'incommunicable': 'None of these attributes is completely communicable. It is better to say that those attributes we call "communicable" are those that are more shared with us' (Grudem 1994:157) 


\section{The creation of humans}

After the creation of Adam, 'God saw all that he had made, and it was very good' (Gn 1:31). Adam was created 'in the image of God', but he was obviously not the same as God: 'You have made him a little lower than God' (Ps 8:5). God has free will ${ }^{17}$ and is impeccable in his nature. Adam also has some free will, ${ }^{18}$ but he is peccable in nature. ${ }^{19}$ Warfield (2001:11) wrote: '[We have] freedom of the will, which was the crowning good of our divinely created nature'. However, Adam does not have 'more' free will than God because he can sin and God cannot. ${ }^{20}$ He can sin because he is lower than God and does not share God's attribute of impeccability.

Why doesn't God create Adam with the attribute of impeccability in Eden? Unfortunately, impeccability cannot be given apart from the other attributes of God (because of God's 'simplicity'), ,1 as 'God and his attributes are one' (Berkhof 1941:44). For example, impeccability cannot be given separately from omnipotence. Can Adam receive omnipotence? Is an omnipotent human still a human or is he God?22 For Adam to have impeccability, God would have to create God. ${ }^{23}$ However, a 'created' god is not God, ${ }^{24}$ because God is not 'created'25 but always existed (Ps 90:2). God did not (and could not) create another God, as there can be no

17.'Since then God necessarily wills his own goodness, but other things not necessarily as shown above (Article 3), he has free will with respect to what he does not as shown above (Article 3), he has free will with respect to what he does not necessarily will (Aquinas 1981, 1.19.10). 'But our God is in the heavens, he does Whatever he pleases' (Ps 115:3). Howeve, that does not mean that he is free to do illogical things (e.g. make a square circle) or free to act contrary to his nature (e.g. free to lie). Questions have been raised as to whether God is significantly fre (Morriston 1985:257-264; Wierenga 2002:425-436).

18. Human free will is fairly limited. We have no say on our parentage, looks, talents, social background ... However, we can decide whom we want to marry or not marry at all.

19.'Man's original capacities included both the power not to sin and the power to sin (posse non peccare et posse peccare). In Adam's original sin, man lost the posse non peccare (the power not to sin) and retained the posse peccare (the power to $\mathrm{sin}$ ) - which he continues to exercise. In the fulfilment of grace, man will have the posse peccare taken away and receive the highest of all, the power not to be able to sin, non posse peccare' (Augustine, Enchiridion on Faith. Hope, and Love, Chapter XXVIII, Note 229, 105).

20.God 'seems constitutionally incapable of choosing (or even wanting) to do what is wrong. According to Plantinga's description of morally significant free will, it does not seem that God would be significantly free' (James Beebe, 'Logical problem of evil', Internet Encyclopedia of Philosophy, http://www.iep.utm.edu/evil-log/). Humans' ability to sin is not a proof of a greater free will. It is a result of their lack of impeccability, an attribute that belongs to God.

21.Augustine discussed the 'simplicity' of God in De Trinitate [The Trinity] (VI.6 and VI.8).

22.Someone may say: ' $[w]$ hat about Christ? He is omnipotent and impeccable and yet he is a man! Therefore, God could make humans impeccable'. The question whether Christ is impeccable or not is subject to much debate and has not been resolved. See (Canham2000:93-114). Also see McKinley (2011:29-66). Whether Christ was impeccable or not, that does not prove that God can make humans impeccable. Christ is God but 'became flesh and dwelt among us' (Jn 1:14). As God impeccable. Christ is God but 'became flesh and dwelt among us' (Jn 1:14). As God, Christ already has the attribute of impeccability. A related question can be raised:
'Did Jesus give up some of his divine attributes while on earth (the kenosis theory)? Did Jesus give up some of his divine attributes while on earth (the kenosis theory)? ... The word kenosis is taken from the Greek verb kenoo, which generally means "to empty" ... The emptying
(Grudem 1999:240).

23.Schellenberg claimed that God could (and should) give finite beings 'good-withoutevil' (i.e. impeccability). 'God's motive in creating the world is the motive to share with finite beings good-without-evil' (Schellenberg 2013:44). However, this is not possible because God cannot create humans with God's attribute of impeccability.

24.'God cannot create something uncreated. In other words, God cannot create God' (Cary 2017:21).

25.Carder affirmed: 'The central notion of Traditional Theism, that God exists as the uncreated creator and that all objects existing beyond God have the source of their being in the creative activity of God' (Eddy Carder, 'Platonism and theism'. Internet Encyclopedia of Philosophy. https://www.iep.utm.edu/pla-thei/). other God but one (Is 45:5). ${ }^{26}$ The idea of God creating an 'uncreated' God is utterly illogical!

Thus, Adam was created 'lower than God', with (limited) free will and the ability to $\sin ^{27} \mathrm{He}$ lived in a state of innocence, ${ }^{28}$ in a close relationship with God, and without the knowledge of good and evil. ${ }^{29}$

\section{The fall of Adam and the origin of evil on earth}

How did Adam, who was created sinless, innocent and 'very good' (Gn 1:31), fall into evil? Cary (2017:22) averred: 'The first sin does not originate from one good thing corrupting another but from a good thing corrupting itself'. The question then becomes, 'How can a good thing corrupt itself?' Did the 'very good' somehow spontaneously deteriorate and corrupt itself into evil? If God could make gold that never deteriorates into lead, why couldn't he make a 'very good' creation that never deteriorates into evil? $?^{30}$ Craig (2017b) observed:

$[T]$ he answer to the question why God made corruptible things cannot be that it belongs essentially to creatures to be corruptible, unless one gives up the view that in the new creation, we will be unable to sin and to get sick and die. (p. 144)

Creatures in heaven are not corruptible and cannot $\sin (\mathrm{Rv}$ 21:27). Henderson (2017:181) said: 'Once in heaven, the redeemed will forever be completely virtuous and incapable of sinning'. If so, how can an innocent and very good creature in idyllic Eden fall into evil?

Did God 'causally determine', 'foreknow but allow' or 'actualise' a chosen world in which Adam would definitely disobey and $\sin ?^{31}$ If so, was God liable for Adam's fall? Hasker (2017) raised the issue of God's accountability:

God, facing no constraints other than that of logical consistency, has deliberately chosen that every instance of sin and evil

26. He (God) could carefully select from among the many possibilities a suitably good one in which everyone happened to choose the good at all times. Then he could have a world with free choices that is also free of the evil consequences of the misuse of freedom' (Connor 2002:307). Unfortunately, there is no such possibility for God to actualise.

27. Angels also had the capacity to $\sin$ (i.e. peccable), and some of them did $\sin$ and rebel against God. 'The devil has sinned from the beginning' (Jn $13: 8$ ). 'And angels who did not keep their own domain, but abandoned their proper abode, He has kept in eternal bonds under darkness for the judgment of the great day' (Jud 6). Whether the 'good angels' can still sin and fall is not addressed in the scriptures.

28.'Many authorities of the Saints declare that man possessed grace in the state of innocence' (Aquinas 1981, 1.95.1).

29.Does God have knowledge of good and evil? One would have to say yes, because God is omniscient. Nevertheless, such knowledge does not lead to evil and sin because God is impeccable. On the contrary, Adam, being created as a peccable being, cannot successfully handle the knowledge of good and evil. Thus, God commands him to abstain from such knowledge.

30.John Hick wrote: 'The basic criticism, then, is that a flawless creation would never go wrong and that if the creation does in fact go wrong the ultimate responsibility for this must be with its creator' (Hick 1990:43).

31.'If the act is according to the agent's desires, then even though the act is causally determined, it is free, and the agent is morally responsible' (Feinberg 1986:37). 'If God foreknows that Adam will sin, then Adam will sin - that's beyond dispute' (Hunt 2001:75). ' $\mathrm{He}[\mathrm{God}]$ is dealt a hand of cards having all true counterfactuals of creaturely freedom printed on them ... God must now play with the hand he has been dealt, that is to say, actualize a world that is feasible for him given the been dealt, that is to say, actualize a world
counterfactuals that are true' (Craig 2017:38). 
should occur exactly as it does occur, and has taken all the steps necessary to guarantee that this will happen. The persons who commit the sins are fully responsible and guilty for them (and some will suffer in hell eternally because of them), even though there was never any real possibility that they would do otherwise. And on the other hand, God, who is the author of this drama, is entirely free of any guilt or responsibility. (p. 53)

Is God culpable for the Fall and evil in the world? When he was created, Adam was warned by God not to eat from the 'tree of the knowledge of good and evil'. ${ }^{32}$ Van Inwagen (2002) opined:

[W] hile they may have been unlike us in many ways, they were not children and were at least as intelligent as we; they fully understood the warning and the wisdom and authority of its Source. (p. 373)

As suggested in the 'quantum proposal', ${ }^{33}$ God created two real options for Adam to choose from: the path of obedience and life or the path of disobedience and death. ${ }^{34}$ In love, God gave him a clear warning, explained the outcomes of the two options and forbade him from selecting the disobedient (evil) scenario. He was then free ${ }^{35}$ to make his own decision without any coercion and without God's physical presence. ${ }^{36}$

After some time in the Garden of Eden, Adam freely chose to disobey $\operatorname{God}^{37}$ and lost his state of innocence. He committed evil in his rebellion and was no longer holy and sinless. His 'iniquities have made a separation between him' (Is 59:2) and his God (Heb 12:14). The Holy God and the disobedient and unholy Adam can no longer live together in close communion.

32.'Evil' is the Hebrew 'Ra' with the meanings 'bad, evil, wicked, adversity, calamity and wrong' (Brown 1997:948-949).

33.Thai (2019). The 'quantum proposal' argues that the sovereign Lord sometimes offers humans some options within his predetermined boundaries (Jos 24:15). This is not to say that options are always offered. Sometimes, God foreordains only one path, as shown in the example of John the Baptist being the forerunner of Christ, even from his mother's womb (Lk 1:14-17).

34.The path of disobedience and death is a logical requirement, a metaphysical necessity for humans to have free will to obey (i.e. good) or disobey (i.e. evil) God.
As asserted by Augustine, evil is 'the privation of the good' rather than an As asserted by Augustine, evil is 'the privation of the good' rather than an wrote: 'It is important to realize, in the light of the doctrine of creation, that every wrote: 'It is important to realize, in the light of the doctrine of creation, that every
being created by God is in itself good, that evil is not a thing in itself (as it was for
Augustine's Manichean opponents) but rather a defect or corruption in what is essentially good and valuable' (Hasker 2017:152). Plantinga said: 'To create creatures capable of moral good, therefore, he must create creatures capable of moral evil; and he can't give these creatures the freedom to perform evil and at the same time prevent them from doing so' (Plantinga 1977:30). Thus, God is not morally at fault for the presence of evil in the world.

35. Humans have free will to choose between the two paths created and foreknown by God (good and life or evil and death). Because God wants his creatures to frely and freely and voluntarily love and obey him, he gives humans free will to choose to As it is illogi (resulting in 'good") demand that he give humans free will (to obey or disobey) and at the same tim insist on precluding any possibility of disobedience. It is a matter of logical requirement rather than a self-limitation of God's omnipotence or omniscience as claimed by some scholars. See Reichenbach (1986:101-124); also see Pinnock (1986:143-162).

36.The omnipresent God was 'not present' when Eve and Adam decided to eat the fruit. Adam was not influenced in any way in his decision to obey or disobey as God intentionally stayed out of the picture.

37.According to the Bible, the talking serpent was Satan ('the dragon, the serpent of old, who is the devil and Satan'; Rv 20:2). Eve was tempted by the serpent, ate the fruit and gave it also to her husband Adam (Gn 3:6). Obviously, Adam could have fruit and gave it also to her husband Adam (Gn 3:6). Obviously, Adam could have refused to eat the forbidden fruit offered by his wife. He could have asked God how to proceed. Sadly, Adam selected the forbidden option. Because Adam was given two options (i.e. abey or disobey) and was commanded by God to choose the path of obedience, Adam was fully responsible for his action and would have to live with the consequences. Adam could not blame his disobedience on the serpent, Eve or God.
He had to depart and live away from God's presence (i.e. Paradise lost). ${ }^{38}$

The path (i.e. world) chosen by Adam was not the most perfect world. It was neither the best of all possible worlds, ${ }^{39}$ nor 'the best possible means of achieving the best possible world'. ${ }^{40}$ It was the forbidden way that condemned Adam and all his descendants ${ }^{41}$ to untold miseries, as they had to live far away from God's presence and protection.

The obedient path would have been a more perfect world (if not the perfect world) as Adam could continue in fellowship with God in the total absence of evil, yet with some free will to make decisions within the boundaries set by God (e.g. care for the garden). ${ }^{42}$ Sadly, Adam forfeited this option when he chose to disobey and spurn God's advice.

The origin of moral and natural evils in this world stems from Adam's poor choice of rebellion and disobedience. For this disaster, Adam had no one to blame but himself! Because he had wished to know evil, after the Fall, he and his descendants experienced evil in full measure, away from the blessed Eden and God's protecting influence.

The pandemic of coronavirus disease 2019 (COVID-19), with more than 2 million people infected and 120000 deaths (as of April 2020), was thought to originate from a wet market in Wuhan, China, where live animals were caged and butchered in unsanitary conditions. Dr Baker, an immunologist studying viruses, said:

[T]hese wet markets have been identified as an issue because you do have species interacting ... It's an opportunity to highlight the dangers of them and an opportunity to clamp down on them. ${ }^{43}$

In spite of the continuing horrendous death toll and the collapse of the worldwide economy, have we learned our 38.The term is borrowed from Milton's famous book (Milton 2003).

39. Leibniz believed that this world is the best possible world, as the omnibenevolent God must create the best world for his creatures. 'I have gone even farther, in the work, and have even proved that this universe must be in reality better than every other possible universe' (Leibniz 1951:96). Leibniz also believes that this is the best possible way for God to fulfil his eternal plan. 'The best plan is not always that which seeks to avoid evil, since it may happen that the evil is accompanied by a greater good' (Leibniz 2015:11).

40.Alcorn (2009:194). Alcorn added: 'A world that had never been touched by evil would be a good place. But would it be the best place possible? If we acknowledge that evil and suffering facilitate the development of significant human virtues, then we must answer no'.

41.The doctrine of the transmission of a sin nature to Adam's descendants is accepted by many Christian theists (e.g. Millard Erickson and Wayne Grudem), though not by all. See Shroyer (2016). Pelagianism claims that Adam's sin nature and guilt are not all. See Shroyer (2016). Pelagianism claims that Adam's sin nature and guilt are not remove sin or guilt. Arminianism avers that Adam's corrupted nature is transmitted remove sin or guilt. Arminianism avers that Adam's corrupted nature is transmitted to his descendants, but the guilt is either not transmitted or is counteracted by
'prevenient grace'. Calvinism teaches that Adam's sin nature and guilt are prevenient grace'. Calvinism teaches that Adam's sin nature and guilt are
transmitted to his descendants (Erickson 2013:565-583). As an analogy, the physical descendants of a slave are also slaves. 'You were slaves of $\sin ^{\prime}$ ( $R m$ 6:17). Thus, all descendants of slaves of $\sin$ are also slaves of $\sin$.

42. How long can this situation (i.e. the 'age of innocence') last? We do not know, as this is not addressed in the Christian scriptures. Was there a specific time frame for the 'age of innocence' after which the 'test of obedience' would be completed and Adam would be 'confirmed' and delivered forever from the possibility of committing evil? Some believed that was the case for Adam. 'If God had not confirmed Adam at the expiration of the specified term, he would have acted ( contrary to truth and faithfulness; and consequently, he would have done wrong,
provided Adam had stood' (Davis 1809:229).

33. Readfearn (2020). Genomic analysis showed that severe acute respiratory 3. Readfearn (2020). Genomic analysis showed that severe acute respiratory
syndrome coronavirus 2 (SARS-CoV-2) (the virus of Covid-19) was likely a zoonotic transfer from animals to humans (Andersen et al. 2020:450-452) 
lesson from this great evil? In April 2020, Wuhan wet markets have reopened to throngs of shoppers searching for freshly slaughtered meat to satisfy their appetite!

As a result of the Fall, humans are now sinful, separated from God and abusing his creation (deforestation, extermination of other species). They no longer recognise God's existence or sovereignty over them. They are too busy carving out their own independent paths and seeking their own pleasures and fulfilments (Rm 1:28-29). Yet, in love and compassion, God did not leave them in their predicament. He provided a rescue plan, a path of salvation for his fallen creatures, through Jesus the Messiah (Jn 3:16). People are free to persist in the way of rebellion and destruction or to take the 'way of escape' (1 Cor 10:13), the option of eternal life offered by Christ to his followers. Thus, God cannot be blamed for the horrendous evils in this world, nor can the calamities be used to deny his existence or benevolence!

\section{How can peccable believers attain 'union with Christ' and impeccability?}

At this time in the present world, according to the apostle Paul, believers are betrothed ${ }^{44}$ to Christ (2 Cor 11:2). The Church is now Christ's future bride (Eph 5:25-27). Believers in heaven will be able to attend the marriage feast as the newly wed (Rv 19:7-8).

Bavinck (2004) wrote concerning God's intended goal of having his 'fully finished image' expressed in a union with:

$[H]$ umanity in its entirety ... the fully finished image, the most telling and striking likeness of God. Scripture clearly teaches all this when it says that the church is the bride of Christ. (p. 577)

Believers will attain impeccability ${ }^{45}$ and union with Christ ${ }^{46}$ through marriage, for 'the two shall become one flesh' (Eph 5:31). They will no longer be able to sin (i.e. free will and no $\sin ):^{47}$

\footnotetext{
44.The Greek harmozo means to betroth, to give one in marriage to anyone' (Thayer's Greek Lexicon, https://biblehub.com/greek/718.htm). Paul will 'present you [the Corinthian church] as a chaste virgin to Christ - at His coming, when the heavenly marriage shall take place (Mt 25:6)' (Jamieson-Fausset-Brown Commentary, https://biblehub.com/commentaries/2_corinthians/11-2.htm).

45. Henderson averred: 'The redeemed in heaven will be impeccable forever' (Henderson 2017:179).

46. Concerning the 'union with Christ', Athanasius wrote: 'For he [Christ] was made man that we might be made God' (Athanasius 1891:93). Aquinas added: 'With regard to the full participation of the Divinity, which is the true bliss of man and end of human life; and this is bestowed upon us by Christ's humanity; for Augustine says in a sermon (xiii, de Temp.): God was made man, that man might be made God" (Aquinas, 1981, III.1.2). Whatever 'union with Christ' may mean, we are not claiming that 1981, III.1.2). Whatever 'union with Christ' may mean, we are not claiming that
humans can become Gods, because God cannot be created. However, we can be humans can become Gods, because God cannot be created. However, we can be
'partakers of the divine nature': 'For by these He has granted to us His precious and magnificent promises, so that by them you may become partakers of the divine nature, having escaped the corruption that is in the world by lust' (Pt 2 1:4).

47.'The traditional view of heaven holds that the redeemed in heaven both have free will and are no longer capable of sinning. A number of philosophers have argued that the traditional view is problematic. How can someone be free and yet incapable of sinning? If the redeemed are kept from sinning, their wills must be reined in. And if their wills are reined in it doesn't seem right to say that they are free. Following their wills are reined in, it doesn't seem right to say that they are free. Following James Sennett, we call this objection to the traditional view of heaven "the Problem of Heavenly Freedom" (Pawl 2009:398-400). Christ being fully God and fully man can take a bride in marriage. This solution also resolves the problem raised by 'God's motive in 'God's motive in creating the world is the motive to share with finite beings goodwithout-evil' (Schellenberg 2013:44). 'Good-without-evil' (i.e. impeccability, 'free will and no sin', just like Christ) can only be given to creatures in a 'union with God'.
}

[I]n the fulfilment of grace, man will have the posse peccare (ability to $\sin$ ) taken away and receive the highest of all, the power not to be able to sin, non posse peccare.

Irenaeus (2018:202) affirmed: 'For by no other means could we have attained to incorruptibility and immortality unless we have been united to incorruptibility and immortality'.

Murray (1984:170) stated that 'union with Christ is the central truth of the whole doctrine of salvation [emphasis added]'. Following their permanent and unbreakable union with Christ (Heb 13:5), humans will be ushered into the eternal state (Th 1 4:17), in an eternal love relationship with him ( $\mathrm{Rm} 8: 37-39)$.

If that is correct, the non-recommended path (our actual world) will eventually lead to the same eternal state (Eden), albeit after a long and horribly painful detour (e.g. the Holocaust), the loss of billions of souls to evil and the required atoning death of Christ for humanity's sins. Thus, God's recommended option (the original path of obedience) is always the better alternative.

\section{Why did God not immediately create impeccable creatures through marriage?}

God's reasons are not explained in the scriptures. ${ }^{48}$ However, it stands to reason that, for a successful union, God wants Adam and Eve to love him freely, without any coercion, as a coerced love ${ }^{49}$ or no-choice love ${ }^{50}$ is no love at all! The French philosopher Sartre (2001) observed:

The man who wants to be loved does not desire the enslavement of the beloved. He is not bent on becoming the object of passion which flows forth mechanically. He does not want to possess an automaton ... The total enslavement of the beloved kills the love of the lover ... the lover does not desire to possess the beloved as one possesses a thing; he demands a special type of appropriation. He wants to possess a freedom as freedom. (p. 230)

Thus, a 'testing ground' of true love and obedience is necessary prior to ushering in a blessed eternal state. Adam's descendants who resolve to love God in this fallen world will be ushered into heaven and delivered from the presence of evil ( $\operatorname{Rv} 21: 27)$. The children of Adam who choose otherwise will be ushered into an eternal state away from God's presence. Created humans with free will and peccability can decide to separate themselves from God or to be 'united with Christ' in an eternal bond of marriage.

48.Nevertheless, humans as creatures have no cause to complain. Irenaeus observed 'For we cast blame upon Him, because we have not been made gods from the beginning, but at first merely men, then at length gods' (Irenaeus 2018:305). Goetz suggests: 'It is because of the existence of the intrinsic good of justice that God does not create everyone in heaven. He cannot create everyone in heaven without acting unjustly' (Goetz 2012:482)

49. Hick said: 'Is it logically possible for God so to make humans that they will freely respond to Himself in love and trust and faith? I believe that the answer is no' (Hick 1985:272). God cannot logically make humans love Him freely.

50.Schellenberg argued that 'an evil-permitting free will apparently cannot be part of any good that God is motivated to share with finite persons in creation ... there is clearly no room to say that the love God would be motivated to facilitate among creatures could come with the possibility of rejection' (Schellenberg 2013:44). creatures could come with the possibility of rejection' (Schellenberg 2013:44).
However, God's perfect love, as one of his attributes, cannot be given to creatures. Thus, creaturely 'love', being imperfect, may come with the possibility of rejection. 


\section{Conclusion}

First, because of his simplicity, God cannot create impeccable beings who never commit evil, an illogical feat tantamount to creating other (uncreated) Gods. Creatures with free will, being lower than God and peccable, can choose to do good or evil and must shoulder full responsibility for their actions.

Second, the presence of evil on earth cannot be blamed on God or used as a reason to deny his existence or question his love. Twain (1935:347) quipped: 'There are many scapegoats for our blunders, but the most popular one is Providence'. God is not the author of evil, as he gives his creatures freedom to love him and live or to spurn his entreaties and die. The state of this earth, whether Blessed Eden or Blighted Hades (COVID-19), is whatever humans make of it as they strive to live independently from God. The calamities wrought by people on their fellow beings (e.g. the Holocaust) cannot be used to deny the existence of a benevolent Lord who kindly provided a path of salvation through Jesus the Messiah. Whether they choose the way of escape (1 Cor 10:13) or persist in the path of destruction is their decision and theirs alone!

Finally, humans can attain impeccability, not through creation, but by a 'union with Christ', for the two shall become one (Eph 5:31-32). Believers will become children of God (Jn 1:12) and partakers of the divine nature (Pt 2 1:4). This everlasting and blessed unity is available to everyone, for 'whoever believes in Him shall not perish, but have eternal life' (Jn 3:16)!

\section{Acknowledgements}

\section{Competing interests}

The authors declare that they have no financial or personal relationships that may have inappropriately influenced them in writing this research article.

\section{Author's contributions}

All authors contributed equally to this work.

\section{Ethical consideration}

This article followed all ethical standards for research without direct contact with human or animal subjects.

\section{Funding information}

This research received no specific grant from any funding agency in the public, commercial or not-for-profit sectors.

\section{Data availability statement}

Data sharing is not applicable to this article as no new data were created or analysed in this study.

\section{Disclaimer}

The views and opinions expressed in this article are those of the author and do not necessarily reflect the official policy or position of any affiliated agency of the author.

\section{References}

Adams, M.M., 2006, Horrendous evils and the goodness of God, Cornell University Press, Ithaca, NY.

Alcorn, R., 2009, If God is good: Faith in the midst of suffering and evil, Multnomah, Colorado Springs, CO.

Andersen, K.G., Rambaut, A., Lipkin, W.I., Holmes, E.C. \& Garry, R.F., 2020, 'The proximal origin of SARS-CoV-2', Nature Medicine 26, 450-452, https://doi. org/10.1038/s41591-020-0820-9

Anselm, 2007. Basic Writings, trans, Thomas Williams, Hackett, Indianapolis.

Aquinas, T., 1981, Summa Theologica, Christian Classics, Notre Dame.

Athanasius, 1891, On the incarnation, 2nd edn., transl. A. Robertson, D. Nutt, London. Bavinck, H., 2004, Reformed dogmatics, vol. 2, Baker Academic, Grand Rapids, MI.

Beebe, J., 2020, 'Logical problem of evil', in Internet Encyclopedia of Philosophy, viewed 03 March 2020, from http://www.iep.utm.edu/evil-log/.

Berkhof, L., 1941, Systematic theology, Eerdmans, Grand rapids, MI.

Brown, F., Driver, S. \& Briggs, C., 1997, The Brown-Driver-Briggs Hebrew and English lexicon, Hendrickson, Peabody, MA.

Brümmer, V., 2006, Brümmer on meaning and the Christian faith: Collected writings of Vincent Brümmer, in J. Hinnells (ed.), Ashgate, Burlington, VT.

Canham, M., 2000, 'Potuit Non Peccare or Non Potuit Peccare: Evangelicals, hermeneutics, and the impeccability debate', The Master's Seminary Journal 11(1), 93-114.

Carder, E., 2020, 'Platonism and theism', in Internet Encyclopedia of Philosophy, viewed 03 March 2020, from https://www.iep.utm.edu/pla-thei/

Cary, P., 2017, 'A classic view', in C. Meister \& J. Dew (eds.), God and the problem of evil, pp. 13-36, IVP Academic, Downers Grove, IL.

Craig, W.L., 2017a, 'A Molinist view', in C. Meister \& J. Dew (eds.), God and the problem of evil, pp. 37-55, IVP Academic, Downers Grove, IL.

Craig, W.L., 2017b, 'The Molinist response', in C. Meister \& J. Dew (eds.), God and the problem of evil, pp. 143-150, IVP Academic, Downers Grove, IL.

Davis, W.C., 1809, The Gospel plan: Or a systematical treatise on the leading doctrines of salvation, Farrand, Mallory and Co, Boston, MA.

Echavarria, A., 2018, 'Aquinas on divine impeccability, omnipotence, and free will', Religious Studies 54, 1-18. https://doi.org/10.1017/S0034412518000367

Erickson, M., 2013, Christian theology, 3rd edn., Baker, Grand Rapids, MI.

Fales, E., 2013, 'Theodicy in a vale of tears', in J.P. McBrayer \& D. Howard-Snyder (eds.), The blackwell companion to the problem of evil, pp. 349-362, John Wiley \& Sons, West Sussex.

Feinberg, J., 1986, 'God ordains all things', in D. Basinger \& R. Basinger (eds.), Predestination and free will: Four views of divine sovereignty and human freedom, pp. 19-43, IVP Academic, Downers Grove, IL.

Gaine, S.F., 2003, Will there be free will in heaven?: Freedom, impeccability and beatitude, T \& T Clark, London.

Goetz, S., 2012, 'The argument from evil', in W.L. Craig \& J.P. Moreland (eds.), The Blackwell companion to natural theology, pp. 449-497, Blackwell, Malden, MA.

Grudem, W., 1994, Systematic theology, an introduction to biblical doctrine, Zondervan, Grand Rapids, MI.

Grudem, W., 1999, Bible doctrine: Essential teachings of the Christian faith, Zondervan, Grand Rapids, MI.

Hasker, W., 2017, 'The open theist response', in C. Meister \& J. Dew (eds.), God and the problem of evil, pp. 151-162, IVP Academic, Downers Grove, IL.

Henderson, L., 2017, 'Heaven', in Y. Nagasawa \& B. Matheson (eds.), The Palgrave handbook of the afterlife, pp. 177-196, Palgrave Macmillan, London.

Hick, J., 1985, Evil and the God of love, MacMillan, London.

Hick, J., 1990, Philosophy of religion, Prentice-Hall, Englewood Cliffs, NJ.

Hick, J., 2017, 'Soul-making theodicy', in N. Dame (ed.), The problem of evil: Selected readings, 2 nd edn., pp. 262-273, University of Notre Dame Press, Notre Dame.

Howard-Snyder, D., 2013, 'The logical problem of evil: Mackie and Plantinga', in J. Mcbrayer \& D. Howard (eds.), The Blackwell companion to the problem of evil, pp. 19-33, John Wiley \& Sons, West Sussex.

Hunt, D., 2001, 'The simple-foreknowledge view', in J. Beilby \& P. Eddy (eds.), Divine foreknowledge: Four views, pp. 65-103, IVP Academic, Downers Grove, IL.

Irenaeus, 2018, Against heresies, in A. Uyl (ed.), Devoted Publishing, Woodstock.

Leibniz, G., 1951, Leibniz selections, Charles Scribner's Sons, New York, NY.

Leibniz, G., 2015, 'Theodicy: A defense of Theism', in M. Rae (ed.), Evil and the hiddenness of God, pp. 10-15, Cengage, Stamford, CT. 
Mackie, J.L., 1955, 'Evil and omnipotence', Mind 64(254), 200-212. https://doi. org/10.1093/mind/LXIV.254.200

McKinley, J., 2011, 'Four patristic models of Jesus Christ's impeccability and temptation', Perichoresis 9(1), 29-66.

Morriston, W., 1985, 'Is God significantly free?', Faith and Philosophy 2(3), 257-264. https://doi.org/10.5840/faithphil19852331

Murray, J., 1984, Redemption accomplished and applied, Eerdmans, Grand Rapids, MI.

O'Connor, T., 2002, 'The problem of evil: Introduction', in W.L. Craig (ed.), Philosophy of religion: A reader and guide, pp. 303-316, Rutgers University Press, New Brunswick.

Otte, R., 2009, 'Transworld depravity and unobtainable worlds', Philosophy and Phenomenological Research 78(1) 165-177. https///doi.org/10.1111/j.1933 1592.2008.00236.x

Pawl, T. \& Kevin T., 2009, 'Incompatibilism, sin, and free will in heaven', Faith and Philosophy 26(4), 398-419. https://doi.org/10.5840/faithphil200926437

Pinnock, C., 1986, 'God limits his knowledge', in D. Basinger \& R. Basinger (eds.) Predestination and free will, pp. 143-162, IVP Academic, Downers Grove, IL.

Plantinga, A., 1974, The nature of necessity, Clarendon Press, Oxford.

Plantinga, A., 1977, God, freedom, and evil, Eerdmans, Grand Rapids, MI.

Plantinga, A., 2009, 'Transworld depravity, transworld sanctity, and uncooperative essences', Philosophy and Phenomenological Research 78(1), 178-191. https:// doi.org/10.1111/j.1933-1592.2008.00237.x

Readfearn, G., 2020, How did coronavirus start and where did it come from? Was it really Wuhan's animal market? viewed 03 March 2020, from https://www. theguardian.com/world/2020/apr/15/how-did-the-coronavirus-start-wheredid-it-come-from-how-did-it-spread-humans-was-it-really-bats-pangolinswuhan-animal-market.

Reichenbach, B., 1986, 'God limits his power', in D. Basinger \& R. Basinger (eds.) Predestination and free will: Four views of divine sovereignty and human freedom, pp. 101-124, IVP Academic, Downers Grove, IL.

Saint Augustine, 1972, The city of God, Penguin, New York, NY.
Saint Augustine, 1996, The enchiridion on faith, hope, and love, Gateway, Washington, DC

Saint Augustine, 2012, De Trinitate (The Trinity), 2nd edn., New City Press, New York, NY.

Sartre, J.P., 2001, Basic writings, in S. Priest (ed.), Routledge, New York, NY.

Schellenberg, J.L., 2013, 'A new logical problem of evil', in J.P. McBrayer \& D. HowardSnyder (eds.), The blackwell companion to the problem of evil, pp. 34-48, John Wiley \& Sons, West Sussex.

Shroyer, D., 2016, Original blessing: Putting sin in its rightful place, Fortress, Minneapolis, MN.

Steinberg, J.R., 2007, 'Leibniz, creation and the best of all possible worlds', International Journal for Philosophy of Religion 62, 123-133. https://doi. org/10.1007/s11153-007-9136-7

Swedenborg, E., 1813, The beauties of Emanuel Swedenborg, transl. R. Socius, Hughes, London.

Thai, L., 2019, Boundaries of freedom: The quantum proposal of divine sovereignty and human responsibility, Resource, Eugene, OR.

Twain, Mark, 1935, Mark Twain's Notebook, Harper \& Brothers, New York.

Van Inwagen, P., 2002, 'The magnitude, duration, and distribution of evil: A theodicy', in W.L. Craig (ed.), Philosophy of religion: A reader and guide, pp. 370-393, Rutgers University Press, New Brunswick.

Warfield, B., 2001, Two studies in the history of doctrines, Wipf and Stock, Eugene, OR.

Wierenga, E., 1989, The nature of God: An inquiry into divine attributes, Cornell University Press, Ithaca, NY.

Wierenga, E., 2002, 'The freedom of God', Faith and Philosophy 19(4), 425-436. https://doi.org/10.5840/faithphil200219447

Williams, T., 2007, Anselm: Basic writings, Hackett, Indianapolis, IN.

Wittman, T., 2018, 'On the unity of the trinity's external works: Archaeology and grammar', International Journal of Systematic Theology 20(3), 359-380. https:// doi.org/10.1111/ijst.12294 